\title{
Pola Spasial Persebaran Penyakit TB Paru Di Kota Malang
}

\author{
Endang Surjati ${ }^{1^{*}}$ \\ ('Program Studi Pendidikan Geografi, Universitas Kanjuruhan Malang, \\ Malang 65148, Indonesia) \\ Email : *surjati@unikama.ac.id
}

Dikirim : 01 Februari 2020

Diterima: 31 Maret 2020

\begin{abstract}
Abstrak: Penyakit TB Paru menyebabkan kematian nomor tiga terbesar di Indonesia yang banyak diderita oleh kelompok usia produktif kerja dan golongan ekonomi lemah. Penularan penyakit TB Paru dapat secara langsung ataupun tidak langsung. Tujuan penelitian ini adalah untuk mengetahui pola sebaran prevalensi TB Paru di Kota Malang dan mengetahui faktor-faktor yang berpengaruh terhadap prevalensi TB Paru di Kota Malang. Penelitian ini dengan menggunakan metode nearest neighbor ratio (NNR) untuk mengetahui pola sebaran spasial penyakit TB Paru di Kota Malang. Nilai Nearest Neigborhood Ratio untuk setiap kecamatan di Kota Malang adalah $<1$, maka pola sebaran penyakit TB Paru di Kota Malang membentuk pola spasial cluster.
\end{abstract}

Kata kunci: tuberculosis, nearest neigborhood, cluster

\begin{abstract}
Pulmonary TB disease causes the third largest death in Indonesia, which is suffered by many productive working age groups and economically weak groups. Transmission of pulmonary TB disease can be directly or indirectly. The aims of this study was to determine the distribution patterns of the prevalence of pulmonary TB in Malang and to know the factors that influence the prevalence of pulmonary TB in Malang. This study uses the nearest neighbor ratio (NNR) method to determine the spatial pattern of pulmonary TB disease in Malang. Nearest Neigborhood Ratio value for each district in Malang is <1, it was indicates that the spatial pattern of pulmonary TB forms a clustered spatial pattern
\end{abstract}

Keywords: tuberculosis, nearest neigborhood, cluster

\section{Pendahuluan}

Menurut laporan WHO tahun 2013, prevalensi TB di Indonesia menempati urutan ketiga setelah India dan China yaitu hampir 700 ribu kasus, angka kematian masih tetap 27/100 ribu penduduk (Suharyo, 2013). Penyakit TB Paru menyebabkan kematian nomor tiga terbesar di Indonesia yang banyak diderita oleh kelompok usia produktif kerja dan golongan ekonomi lemah (Ruswanto, 2010). Penyakit TB Paru merupakan penyakit kronis dan menular. Penularan penyakit TB Paru dapat secara langsung ataupun tidak langsung. Kematian akibat penyakit ini memiliki prevalensi yang besar, hal ini karena setiap tahun muncul 500 ribu kasus baru dan lebih dari 140 ribu kasus lainnya meninggal (WHO, 2013).

Studi epidemiologi mempelajari hubungan antara kondisi lingkungan dan dampak negatifnya terhadap kesehatan pada manusia. Dampak negatif yang bisa dialami oleh manusia bisa terjadi kapan saja, misalnya pada masa anak-anak, dewasa ataupun orang tua yang ditimbulkan oleh adanya racun yang ditimbulkan oleh kondisi lingkungan seperti pencemaran udara dan limbah industri. Selain itu, studi epidemiologi juga menjelaskan mengenai faktor lingkungan yang mempengaruhi kesehatan masyarakat seperti pestisida, produk dalam air minum, dan daya dukung lingkungan itu sendiri. Keterbatasan dalam kesehatan masyarakat 
yang terkena dampak adalah bahwa pengaruh lingkungan terhadap kondisi kesehatan masyarakat hanya dapat diketahui setelah manusia terkena suatu penyakit.

Komponen segitiga epidemiologi yang berperan dalam menyebabkan kejadian penyakit, yaitu agen, manusia dan lingkungan. Bibit penyakit (agent) dari TB Paru ditularkan oleh penderita tuberculosis yang mengeluarkan dahak disembarang tempat. Penyakit TB Paru ditularkan oleh basil Mycobacterium tuberculosis. Kuman tersebut dapat bertahan lama dalam lingkungan yang lembab dan akan cepat mati apabila terkena cahaya matahari secara langsung. Kuman yang masih hidup dan terhirup oleh manusia akan dapat menimbulkan infeksi dan menyebabkan penyakit apabila daya tahan tubuh manusia lemah. Penyakit TB Paru akan cepat menular dengan semakin dekatnya hubungan antara penderita dengan orang yang bukan penderita (Drobniewski, 2013).

Penelitian epidemiologi semakin berkembang dengan dimanfaatkannya teknologi Penginderaan jauh dan Sistem Informasi Geografis. Penelitian terkait dengan lokasi geografi (spasial) telah dilakukan sejak pada penelitian mengenai penyelidikan terkait distribusi geografi penyakit Yellow fever (1879) dan kasus kolera (1850) (Chang, 2012). Saat ini penelitian epidemiologi semakin berkembang dengan berbagai pendekatan metode. Penginderaan jauh dan Sistem Informasi Geografis telah dipergunakan untuk melakukan pemetaan lokasi penyakit dan penyebab penyakit, melakukan monitoring untuk membantu dalam surveilans dan melakukan intervensi untuk pencegahan penyakit.

Endemi penyakit dipengaruhi oleh faktor sosial ekonomi, lingkungan dan keturunan. Kondisi sosial dan ekonomi masyarakat dengan tingkat social dan pendidikan yang rendah dapat meningkatkan potensi penularan penyakit (Wahyuni et. al. 2003). Lingkungan yang lembab, gelap dan tidak memiliki ventilasi memberikan andil besar bagi seseorang terjangkit TB Paru. Kuman TB Paru akan cepat mati bila terkena sinar matahari, terkena panas api atau air mendidih, terkena sabun, lisol, karbol atau sejenisnya. Selain lingkungan , pola hidup yang kurang bersih dan sehat juga dapat menyebabkan timbul kembali penyakit TB Paru dan juga dapat menimbulkan penderita baru.

Penyelidikan kejadian penyakit juga dapat dianalisis menggunakan metode statististik spasial. Beberapa penelitian telah dilakukan terkait dengan analisis spasial kejadian penyakit, seperti Kammere (2013) menguji perbandingan efektifitas metode statistik (LLR, CUSUM dan SatScan) untuk mendeteksi kejadian luar biasa penyakit infeksi. Penelitian tersebut menunjukkan bahwa ketiga metode tersebut mempunyai performan yang sama dalam melakukan deteksi awal yang memungkinkan untuk dilakukan intervensi dengan cepat sehingga dapat menghindari potensi bertambahnya kasus TB. Chang et. al. (2012) menggunakan metode statistik spasial untuk mengetahui dependensi spasial kejadian penyakit TB di Taiwan. Metode autokorelasi spasial yang dipergunakan adalah dengan menggunakan Moran's I. Gomes (2012) dan Simoonga (2009) melakukan penelitian untuk mengetahui hubungan antara transmisi schistosomiasis dan faktor lingkungan dengan pendekatan PJ dan SIG dan memperkirakan wilayah yang mungkin terjadi penyakit tersebut. Studi mengenai distribusi Mycobacterium tuberculosis galur Beijing pada TB paru BTA (+) pasien di RSU di Kota Malang dilaksanakan dengan metode spoligotyping, yaitu dengan memeriksa dahak dari 42 sampel pasien untuk mengetahui karakteristik isolat $M$. tuberculosis genotip Beijing dan no Beijing (Yudani dan Astuti, 2010). Sebaran geografi TB Paru perlu diketahui untuk mengetahui faktor-faktor penyebab terjadinya penyakit.

Berdasarkan data yang diperoleh dari Dinas Kesehatan Malang bahwa penderita TB Paru di Kota Malang berjumlah 1.670 penderita (Dinkes Kota Malang 2011). Jumlah ini nomor 3 setelah Diare dan Pneumonia. Data mengenai kejadian penyakit TB Paru yang ada di Kota Malang masih dalam bentuk data statistik, sehingga untuk mengetahui pola persebaran spasial kejadian penyakit TB Paru masih mengalami kesulitan. Dengan mengetahui pola 
persebaran penyakit TB paru dapat membantu dalam proses pelayanan kesehatan terhadap penyakit tersebut. Pola persebaran spasial menyajikan informasi mengenai lokasi kejadian penyakit dan kondisi lingkungan yang merupakan salah satu factor penyebab terjadinya penyakit TB Paru.

Pengumpulan data secara survei medan membutuhkan waktu dan biaya yang besar. Untuk melakukan efisiensi waktu dan mengurangi biaya, maka dalam melaksanakan survei medan diperlukan alat bantu berupa data-data geosapasial. Data geospasial merupakan datadata yang berbasis geo-referensi, artinya bahwa data-data tersebut mempunyai komponenkomponen yang terkait dengan spasial. Dengan menggunakan data spasial, untuk menangani kasus kejadian penyakit TB Paru dapat dilakukan dengan cepat. Selain itu dengan mengetahui bagaimana arah penularannya akan dapat diketahui bagaimana cara pencegahan terhadap penyakit tersebut.

Tujuan penelitian ini adalah untuk mengetahui pola sebaran prevalensi TB Paru di Kota Malang dan mengetahui faktor-faktor yang berpengaruh terhadap prevalensi TB Paru di Kota Malang. Penelitian ini dengan menggunakan metode nearest neighbor ratio (NNR) untuk mengetahui pola sebaran spasial penyakit TB Paru di Kota Malang. Citra Quickbird dipergunakan untuk mengetahui informasi spasial wilayah penelitian.

\section{Metode Penelitian}

\section{Lokasi}

Malang secara astronomis terletak pada posisi $112.06^{\circ}-112.07^{\circ}$ Bujur Timur , $7.06^{\circ}-8.02^{\circ}$ Lintang Selatan. Luas wilayah Kota Malang sebesar $110,06 \mathrm{~km}^{2}$ yang terbagi dalam lima kecamatan yaitu Kecamatan Kedungkandang, Kecamatan Sukun, Kecamatan Klojen, Kecamatan Blimbing dan Kecamatan Lowokwaru. Sebaran spasial penyakit TB Paru dilakukan dengan melakukan spasialisasi data kasus prevalensi dengan menggunakan GPS. Selanjutnya deilakukan analisis spasial dengan menggunakan metode analisis Nearest Neighboor. Citra Quickbird dipergunakan untuk mendapatkan data parameter lahan berupa kepadatan bangunan dan membuat peta dasar.

\section{Pengumpulan Data}

Data lokasi kejadian penyakit TB Paru diperoleh dari masing-masing UPT Puskesmas setiap kecamatan di Kota Malang. Peta dasar diperoleh dari peta RBI Kota Malang dan Citra Quickbird. Peta kepadatan bangunan diperoleh menggunakan algoritma Normalized Difference Built up Index (NDBI) meggunakan Citra Quickbird. Data penderita penyakit TB Paru dan kepadatan penduduk diperoleh dari BPS Kota Malang dan masing-masing UPT di Kota Malang.

Jumlah penderita TB Paru berdasarkan data yang diperoleh dari Dinas Kesehatan Kota Malang berjumlah 1670 penderita TB Paru pada tahun 2011 (BPS Kota Malang, 2011). Pengambilan sampel dilakukan dengan menggunakan metode proposional sampling. Pengambilan sampel dengan mengambil $30 \%$ dari jumlah penderita dan disesuaikan dengan kondisi pada masing-masing kecamatan.

\section{Analisa Data}

Analisa data dalam penelitian ini menggunakan pendekatan analisis statistik spasial dengan metode Nearest Neighbor. Pengujian Nearest Neighbor Analysis dilakukan dengan mendasarkan pada perbandingan rata-rata jarak yang akan diukur dengan pola titik yang telah diketahui (Lee\&Wang, 2001). Jika rata-rata jarak yang diukur lebih besar dari pola random, maka dikatakan titik tersebut mempunyai pola yang terpencar. Sebaliknya apabila rata-rata 
jarak yang diukur lebih kecil daripada pola random, maka dikatakan titik tersebut mempunyai pola kluster.

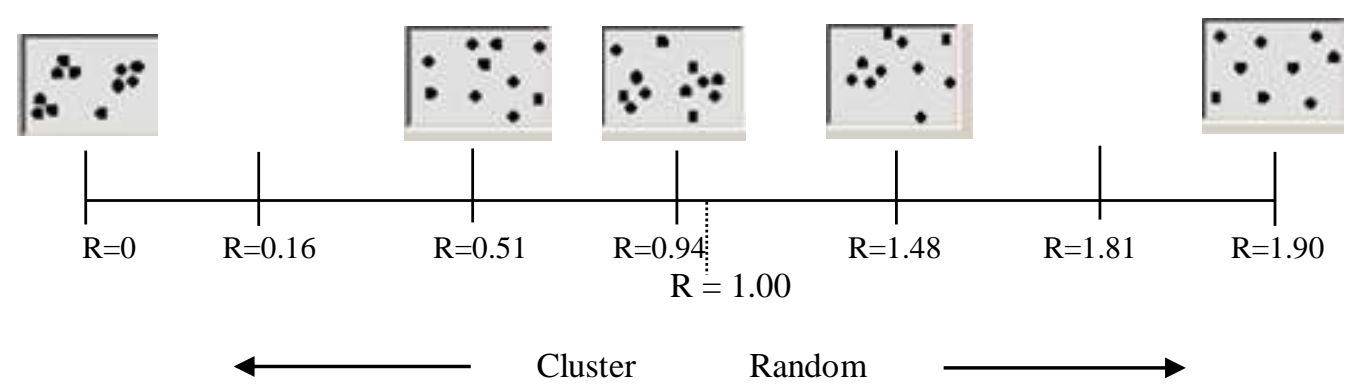

Gambar 1. Skala $R$ statistic

\section{Menentukan tingkat signifikan dari aglomerasi distribusi titik (kasus TB Paru)}

Nearest Neighbor Analysis dipergunakan untuk mengukur tingkat perbedaaan rata-rata jarak yang diteliti terhadap rata-rata jarak yang diharapkan. Sedangkan untuk mengetahui besarnya perbedaan tersebut dengan menghitung standard error (SEr). Stadard error menggambarkan kemungkinan-kemungkinan perbedaan yang terjadi semata-mata disebabkan oleh adanya perubahan yang ada. Jika jarak yang dihitung relatif kecil ketika diperbandingkan dengan standar error, dikatakan bahwa perbedaan tersebut tidak signifikan. Sebaliknya, jika jarak yang dihitung relatif besar apabila diperbandingkan dengan standar error, maka dikatakan bahwa perbedaan tersebut signifikan.

Persamaan yang dipergunakan untuk mengetahui stadard error jarak yang terukur adalah sebagai berikut:

$$
\mathrm{SEr}=\frac{0.26136}{\sqrt{\mathrm{n}}^{2} / \mathrm{A}}
$$

Selanjutnya untuk mengetahui tingkat signifikan tingkat aglomerasi dari pola distribusi titik dapat mempergunakan persamaan berikut:

$$
\mathrm{ZR}=\frac{\text { robs }- \text { rexp }}{\mathrm{SEr}}
$$

Semua tahapan proses perhitungan di atas dilakukan dengan menggunakan bantuan program pengolahan data spasial yaitu ArcGIS versi 9.3

\section{Hasil dan Pembahasan \\ Kondisi Geografi}

Kondisi iklim Kota Malang selama tahun 2010 tercatat rata-rata suhu udara berkisar antara $23,2^{\circ} \mathrm{C}-24,4^{\circ} \mathrm{C}$. Sedangkan suhu maksimum mencapai $29,2^{\circ} \mathrm{C}$ dan suhu minimum $19,8^{\circ}$ C. Rata-rata kelembaban udara berkisar $78 \%$ - 86\%. Dari hasil pengamatan 
Stasiun Klimatologi Karangploso, curah hujan yang relatif tinggi terjadi pada bulan Januari, Februari, Maret, April, dan Desember. Sedangkan pada bulan Juni, Agustus, dan Nopember curah hujan relatif rendah.

Kota Malang terletak pada ketinggian sekitar 440 - 667 meter di atas permukaan air laut. Salah satu lokasi yang paling tinggi adalah Pegunungan Buring yang terletak di sebelah Timur Kota Malang. Sedangkan sungai yang mengalir di Wilayah Kota Malang adalah Sungai Brantas, Sungai Amprong dan Sungai Bango.

Jenis penggunaan lahan yang paling luas didominasi oleh lahan permukiman sebesar 4738,07 Ha atau sebesar 43\%. Wilayah permukiman hampir meliputi setengah dari luas di Kota Malang. Hal ini menunjukkan bahwa pengembangan wilayah Kota Malang pesat sekali ditambah dengan pembangunan gedung-gedung perkantoran dalam bentuk rumah toko (ruko). Pertumbuhan kota yang sangat pesat dan dinamika perekonomian yang tinggi menjadikan Kota Malang sebagai Kota Metropolitan kedua setelah Surabaya di Jawa Timur.

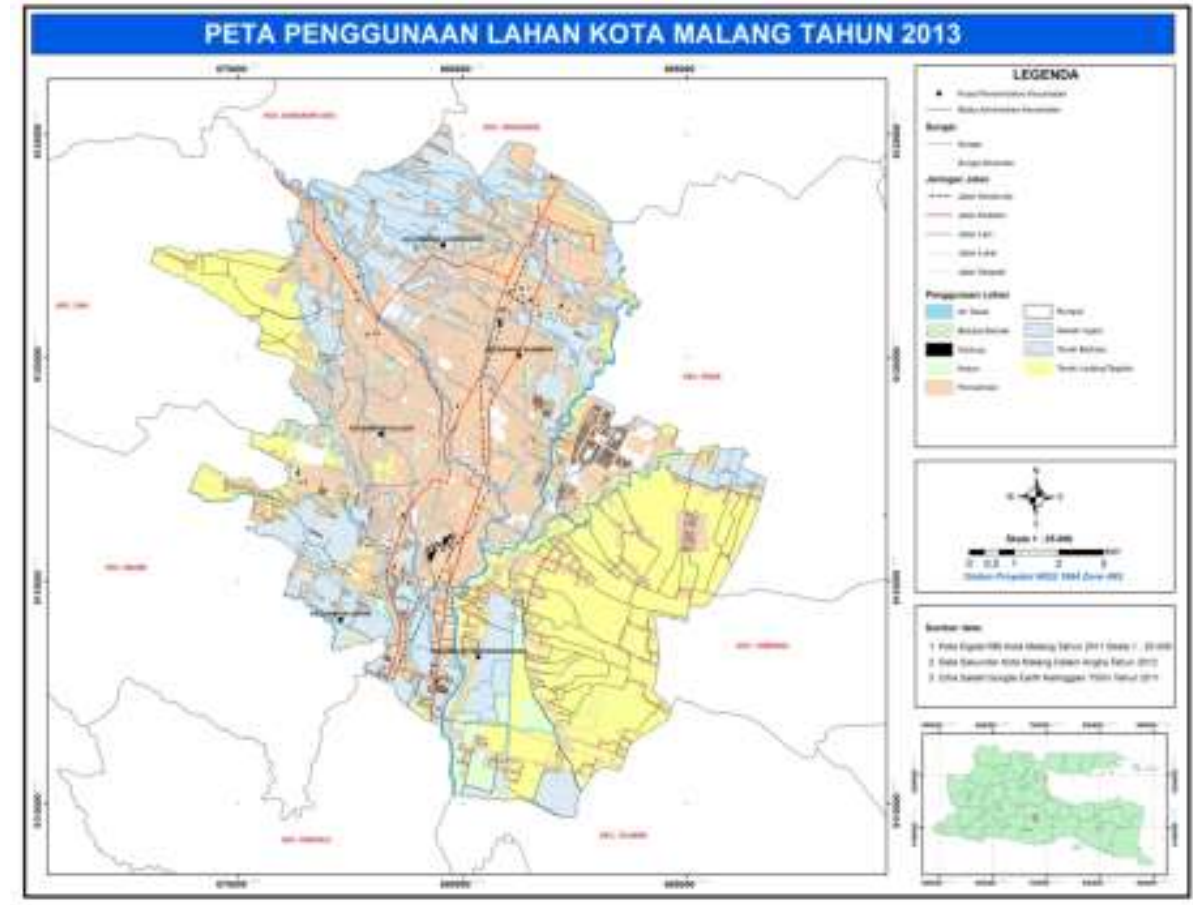

Gambar 2. Peta Penggunaan Lahan Kota Malang

\section{Pola Sebaran Spasial Kasus TB Paru Di Kota Malang}

Sebaran kasus TB Paru di Kota Malang dari yang terbanyak dan terendah, yaitu: Kecamatan Kedungkandang adalah 305 kasus, Kecamatan Sukun adalah 270 kasus, Kecamatan Blimbing adalah 270 kasus, Kecamatan Klojen adalah 198 kasus, dan Kecamatan Lowokwaru adalah 109 kasus (Tabel 1). Kasus TB Paru paling banyak terdapat di Kecamatan Kedungkadang, Kecamatan ini berada di sebelah timur Kota Malang dan berbatasan dengan Kabupaten Malang. Kecamatan Kedungkandang merupakan kecamatan terluas di Kota Malang yang sedang mengalami proses perkembangan wilayah. 
Tabel 1. Penderita TB Paru di Kota Malang berdasarkan usia

\begin{tabular}{llccccc}
\hline $\mathbf{N o}$ & Kecamatan & $\mathbf{< 2 5} \mathbf{T h}$ & $\mathbf{2 5 - 3 9} \mathbf{T h}$ & $\mathbf{4 0 - 5 4} \mathbf{~ T h}$ & $\mathbf{> 5 4} \mathbf{~ T h}$ & Total \\
\hline $\mathbf{1}$ & Kedungkandang & 67 & 119 & 62 & 57 & 305 \\
\hline $\mathbf{2}$ & Sukun & 54 & 107 & 65 & 44 & 270 \\
\hline $\mathbf{3}$ & Klojen & 43 & 55 & 41 & 59 & 198 \\
\hline $\mathbf{4}$ & Blimbing & 56 & 75 & 68 & 71 & 270 \\
\hline $\mathbf{5}$ & Lowokwaru & 32 & 41 & 15 & 21 & 109 \\
\hline & & & & & 1152 \\
\hline
\end{tabular}

Sumber: Puskesmas Kota Malang 2012-2013

Pola sebaran spasial TB Paru Kota Malang dapat dilihat pada gambar 1. Berdasarkan analisis NNR diketahui bahwa nilai pola spasial sebaran penyakit TB Paru di Kota Malang dapat dilihat pada Tabel 2. Seperti yang telah disampaikan pada bagian metode yang dituliskan bahwa nilai signifikan harus diperbandingkan dengan nilai $\mathrm{Z}$ untuk mengetahui tingkat signifikannya.

Tabel 2. Tabel Hasil Analisa Statistik Pola Spasial Sebaran TB Paru Di Kota Malang

\begin{tabular}{lllcc}
\hline No. & \multicolumn{1}{c}{ Kecamatan } & Pola Spasial & Signifikan & Zscore \\
\hline 1 & Blimbing & Cluster & 0.01 & 7.41 \\
\hline 2 & Kedungkandang & Cluster & 0.01 & 9.51 \\
\hline 3 & Klojen & Cluster & 0.01 & 5.64 \\
\hline 4 & Lowokwaru & Cluster & 0.01 & 4.23 \\
\hline 5 & Sukun & Cluster & 0.01 & 5.59 \\
\hline
\end{tabular}

Sumber: Hasil Analisa Data (Tahun 2013)

Penelitian ini bertujuan untuk melihat pola penyebaran kasus TB dengan menggunakan metode nearest neighboor di Kota Malang. Spasialisasi data kasus TB Paru dilakukan dengan melakukan geocoding menggunakan teknologi GPS sebagai pengambilan data primer dari setiap kasus TB. Pendekatan penelitian ini adalah geographicalepidemiology dengan analisa spasial-statistik.

\section{Nearest Neigborhood Ratio}

Metode ini membandingkan antara rata-rata jarak yang didapatkan dari setiap titik dan tetangga terdekatnya, dengan rata-rata jarak yang diharapkan akan muncul jika data mengikuti distribusi normal. Karena data jarak antara setiap kecamatan tidak diketahui, maka dilakukan pendekatan dengan menggunakan jarak Euclidean yang dihasilkan dari pengukuran titik tengah antar fenomena. Dari kumpulan tersebut, diambil jarak terkecil antar dua kasus.

Dari peta penyebaran kasus TB menggunakan pendekatan analisa tetangga terdekat (Nearest Neighboor Analysis) didapatkan nilai R untuk mengetahui pola spasial sebaran kasus TB Paru tersebut, apakah mengelompok (clustered), acak (random) atau seragam (uniform). Parameter tetangga terdekat $R$ tersebut dapat ditunjukkan pula dengan rangkaian kesatuan (continum) untuk mempermudah pembandingan antar pola titik yaitu: $R=1,00$ jika membentuk pola random, $R>1,00$ jika membentuk pola seragam (uniform), $R<1,00$ jika membentuk pola mengelompok (clustered). 


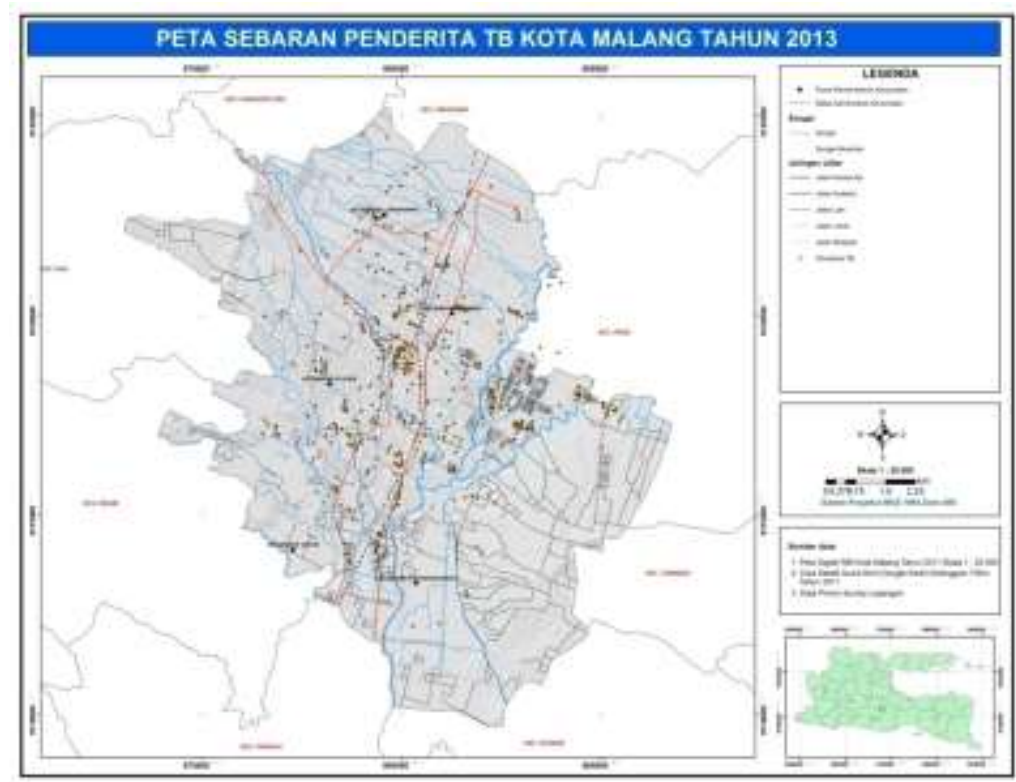

Gambar 3. Peta Persebaran Spasial Kejadian Penyakit TB Paru Di Kota Malang

Hasil analisa Nearest Neigborhood menunjukkan rata-rata koefisien pasien TB di masing-masing Kecamatan di Kota Malang < 1 . Nilai tersebut berarti bahwa tidak terdapat pola yang acak dalam sebaran penyakit TB di Kota Malang dengan kata lain pola sebaran penyakit TB Paru di Kota Malang membentuk cluster.

Sebaran jumlah penduduk setiap kecamatan adalah Kecamatan Lowokwaru memiliki penduduk terbanyak yaitu sebesar 186.013 jiwa, kemudian diikuti oleh Kecamatan Sukun 181.513 jiwa), Kecamatan Kedungkandang (174.477 jiwa), Kecamatan Blimbing ( 172.333 jiwa) dan Kecamatan Klojen (105.907 jiwa). Sedangkan wilayah dengan kepadatan penduduk tertinggi terjadi di wilayah Kecamatan Klojen yaitu mencapai 11.994 jiwa per $\mathrm{Km}^{2}$, sedangkan terendah di wilayah Kecamatan Kedungkandang sebesar 4.374 jiwa per $\mathrm{Km}^{2}$ (Tabel 3).

Tabel 3. Kepadatan Penduduk Kota Malang

\begin{tabular}{llcc}
\hline No & Kecamatan & $\begin{array}{c}\text { Jumlah penduduk } \\
(\text { Jiwa })\end{array}$ & $\begin{array}{c}\text { Kepadatan } \\
\left(\text { Jiwa per Km }^{2}\right)\end{array}$ \\
\hline 1 & Kedungkandang & 187.492 & 4.374 \\
\hline 2 & Sukun & 193.627 & 9.234 \\
\hline 3 & Klojen & 113.994 & 11.994 \\
\hline 4 & Blimbing & 185.907 & 10462 \\
\hline 5 & Lowokwaru & 161.393 & 7.141 \\
\hline \multicolumn{2}{r}{ Sumber: BPS Kota Malang, 2011 } &
\end{tabular}

\section{Dampak Kepadatan Bangunan Terhadap Kejadian TB Paru di Kota Malang}

Lahan terbangun merupakan objek artificial yang berada di atas permukaan Bumi. Objek bangunan mempunyai karakteristik spectral yang tertentu, sehingga objek tersebut dapat dibedakan dengan objek yang lain di sekitarnya dengan berdasarkan nilai pantulan spektralnya. Nilai pantulan spectral dikarakteristikkan berdasarkan angka digital (digital number). Angka digital tersebut selanjutnya dapat dianalisis dengan menggunakan algoritma untuk menghasilkan informasi yang sesuai, dalam hal ini adalah kondisi kepadatan bangunan. 
Algoritma untuk mengetahui kepadatan bangunan dapat menggunakan transformasi Normalized Diferrence Built up Index (NDBI). Transformasi NDBI memanfaatkan saluran inframerah dekat (Near Infrared) dan saluran inframerah tengah (Short Wave Infrared). Pada saluran inframerah dekat, reflektansi lahan terbangun dan terbuka sangat rendah, sedangkan pada saluran inframerah tengah mampu mencerminkan kandungan kelembaban vegetasi dan tanah (Lillesand dan Kiefer, 2004). Persamaan algoritma NDBI yaitu (SWIR NIR)/(SWIR+NIR).

Berdasarkan hasil analisis algoritma NDBI diperoleh peta sebaran peta kepadatan bangunan (Gambar 4). Sebaran spasial kepadatan bangunan sebagian besar banyak terdapat di daerah pusat kota, yaitu berada pada Kecamatan Klojen dan juga pada beberapa kecamatan dengan luasan yang relatif. masih lebih luas Kecamatan Klojen. Kepadatan bangunan mengindikasikan jarak tempat tinggal antar tetangga sangat dekat. Semakin dekat jarak bangunan rumah tinggal, maka memudahkan terjadinya penularan penyakit TB Paru.

Berdasarkan analisis regresi dengan metode Ordinary Least Square (OLS) diperoleh nilai koefisiesn regresi sebesar 16,60. Nilai koefisien secara statistik adalah signifikan, yaitu sebesar $0,00(\mathrm{p}<0.05)$.

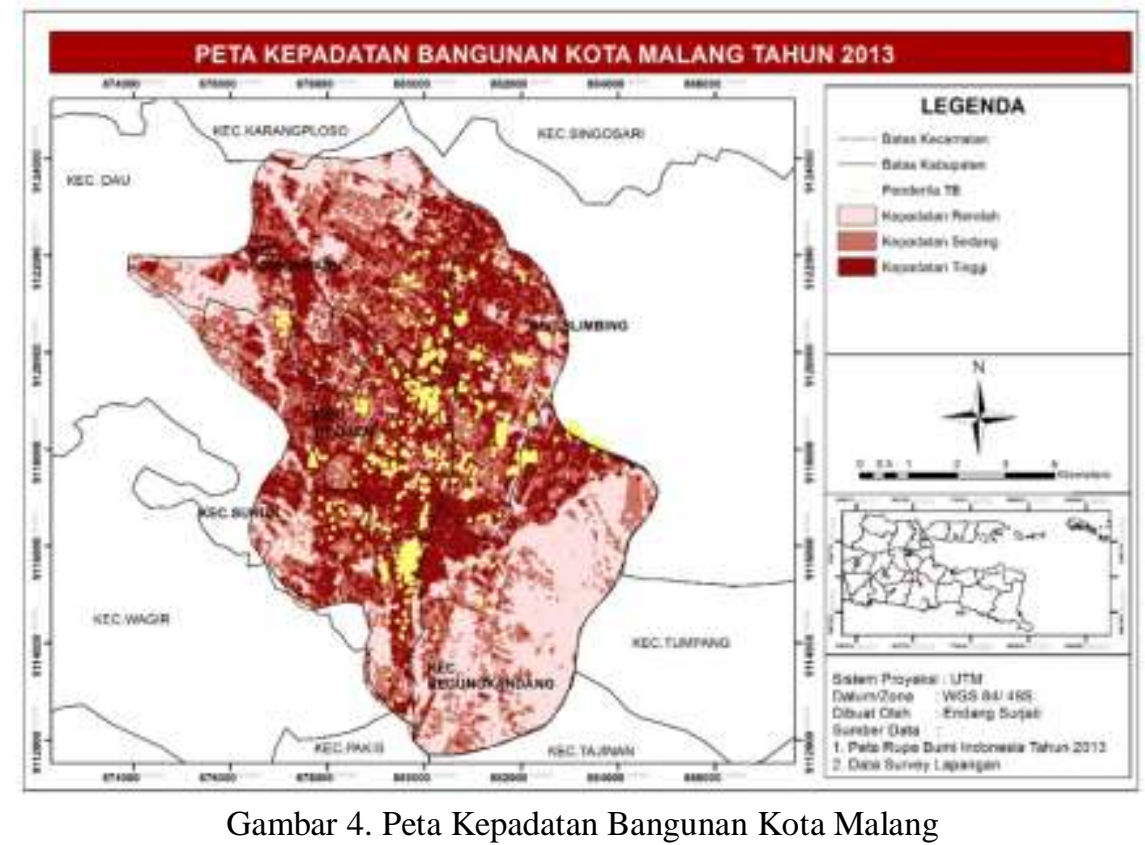

Droplet infection berasal dari droplet nuclei yang berisi kuman TB (Mycobacterium Tuberculosis atau M.TB) dapat dihirup oleh orang yang sehat. Droplet nuclei bisa hilang atau rusak jika ventilasi udara baik karena sinar matahari bisa masuk ruangan dan pemberian sinar ultraviolet. Kuman TB tidak dapat bertahan lama apabila terkena pancaran sinar matahari.

Berdasarkan uraian di atas menunjukkan bahwa terdapat dua faktor penting yang dapat menyebabkan terjadinya penularan penyakit TB yaitu penderita yang menimbulkan droplet nuclei dan lingkungan di sekitar penderita. Droplet nuclei di udara disebabkan karena perilaku penderita yang meludah di sembarang tempat dan ketidakteraturan berobat. Faktor lingkungan penderita antara lain lingkungan perumahan dan tempat kerja. Pada lingkungan perumahan yang buruk dapat menularkan TB pada anggota keluarganya, sedangkan lingkungan tempat kerja yang buruk dapat menularkan TB pada pekerja lainnya.

Faktor perilaku masyarakat (personal hygiene) terkait dengan penularan TB Paru, yaitu kebiasaan meludah, kebiasaan menggunakan alat pelindung diri (respirator) untuk 
melindungi dari pencemaran udara, kebiasaan merokok, dan perilaku berobat bagi penderita TB Paru. Perilaku hidup sehat tersebut merupakan perilaku yang dapat menghindarkan masyarakat terpapar oleh penyakit TB Paru.

Tuberkulosis Paru (TB Paru) merupakan suatu penyakit infeksi yang disebabkan oleh bakteri Mycobacterium tuberculosis. Bakteri ini berbentuk batang dan bersifat tahan asam sehingga dikenal juga sebagai Basil Tahan Asam (BTA). Sebagian besar kuman Tb menyerang paru, tetapi dapat juga menyerang organ tubuh lain. Kuman tuberculosis cepat mati dengan sinar matahari langsung, tetapi dapat bertahan hidup beberapa jam di tempat yang gelap dan lembab. Dalam jaringan tubuh, kuman ini dapat dormant, tertidur lama selama beberapa tahun.

Secara umum riwayat alamiah penyakit terdiri dari: (1) Tahap prepatogenesis, tahap prepatogenesis TB Paru terjadi saat individu berinteraksi dengan penderita TB paru positif yang sangat menular. Pada saat penderita TB Paru positif menyebarkan dahak yang mengandung kuman BTA ke udara, maka individu tersebut dapat menghirup kuman BTA hingga mencapai paru-paru dan (2) Tahap patogenesis. Dalam tahap ini dibagi dalam empat tahap yaitu (Benenson, 1990 dalam Martini 2007)):

1) Tahap inkubasi.

Masa inkubasi TB Paru adalah 4-12 minggu. Pada tahap ini terjadi reaksi daya tahan tubuh untuk menghentikan perkembangan kuman BTA. Walaupun terdapat reaksi daya tahan tubuh, namun ada sebagian BTA yang menetap sebagai kuman persister atau dormant (tidur). Apabila daya tahan tubuh tidak dapat menghentikan perkembangan kuman, maka dalam beberapa bulan akan menjadi penderita TB Paru dan memberikan gejala.

2) Tahap penyakit dini.

Tahap ini dimulai saat penderita mengalami gejala awal penyakit, yang biasanya dikarenakan oleh adanya penurunan daya tahan tubuh, sehingga pada tahap ini terjadi kerusakan paru secara luas.

3) Tahap penyakit lanjut.

Pada tahap ini, penderita TB Paru dapat mengalami komplikasi seperti perdarahan saluran nafas bawah yang dapat menyebabkan kematian, kolaps dari lobus akibat retraksi bronkial, pelebaran bronkus dan pembentukan jaringan ikat, adanya udara di dalam rongga pleura, penyebaran infeksi pada organ lain seperti otak, tulang, persendian dan ginjal.

4) Tahap akhir penyakit.

Pada tahap akhir penyakit, penderita TB Paru dapat menjadi sembuh atau meninggal. Penderita TB Paru dapat sembuh apabila penyakit yang dialami tidak sampai pada tahap penyakit lanjut atau terjadi komplikasi. Penderita juga dapat sembuh apabila dilakukan pengobatan TB Paru yang sesuai. Kematian dapat terjadi bila terdapat komplikasi atau penderita tidak melaksanakan pengobatan yang telah dianjurkan.

Penderita TB Paru yang tidak diobati setelah 5 tahun, maka 50\% dari penderita Tb paru akan meninggal, 25\% akan sembuh sendiri dengan daya tahan tubuh yang tinggi, dan 25\% sebagai "kasus tropik" yang tetap menular (WHO, 1996).

Penderita TB Paru BTA positif, dapat menjadi sumber penularan. Penularan terjadi melalui udara yang tercemar dengan $M$. tuberculosis yang dilepaskan pada saat penderita TB Paru batuk, dan pada anak-anak sumber infeksi umumnya berasal dari penderita TB Paru dewasa. Bakteri ini bila sering masuk dan terkumpul di dalam paru-paru akan berkembang biak menjadi banyak (terutama pada orang dengan daya tahan tubuh yang rendah), dan dapat menyebar melalui pembuluh darah atau kelenjar getah bening. Oleh sebab itulah infeksi TB Paru dapat menginfeksi hampir seluruh organ tubuh seperti: paru-paru, otak, ginjal, saluran 
pencernaan, tulang, kelenjar getah bening, dan lain-lain, meskipun demikian organ tubuh yang paling sering terkena yaitu paru-paru (Crofton, 2002 dalam Martini 2007).

Lingkungan yang mendukung perkembang biakan dari kuman TB adalah faktor kelembaban udara, kepadatan bangunan, wilayah dengan tingkat polusi yang tinggi, dan juga kondisi sosial ekonomi yang masih rendah. Udara yang lembab sangat mendukung pertumbuhan dari kuman $\mathrm{TB}$, karena udara yang lembab berkaitan dengan intensitas penyinaran matahari yang kurang sehingga menyebabkan kuman TB berkembang sangat subur. Kepadatan bangunan erat kaitannya dengan kepadatan penduduk yang terdapat dalam suatu wilayah tertentu. Semakin padat penduduk dalam suatu wilayah maka semakin tinggi resiko penularan penyakit TB Paru.

Di atas telah disampaikan ada beberapa faktor yang dapat menyebabkan meningkatnya penularan penyakit TB paru. Faktor lingkungan tempat kerja memberikan peran yang sangat besar karena dapat menjadi media penularan TB dan dapat menurunkan kualitas faal paru yaitu adanya pencemaran debu yang tinggi, ventilasi dan hygiene tempat kerja yang tidak baik. Beberapa macam debu dapat menurunkan kualitas faal paru.

Faktor lingkungan perumahan memegang peranan penting dalam menentukan terjadinya proses interaksi antara penjamu dengan unsur penyebab dalam proses terjadinya penyakit. Lingkungan fisik meliputi kepadatan hunian (rasio jumlah kamar tidur dan orang), ventilasi, dan suhu ruangan (Apriani, 2001).

Kepadatan penghuni sebagai stimulus suatu proses penularan penyakit. Semakin padat hunian maka perpindahan penyakit, khususnya penyakit menular melalui udara akan semakin mudah dan cepat, apalagi terdapat anggota keluarga yang menderita TB Paru dengan BTA (+). Kuman TB Paru cukup resisten terhadap antiseptik tetapi dengan cepat akan menjadi inaktif oleh cahaya matahari, sinar ultraviolet yang dapat merusak atau melemahkan fungsi vital organisme dan kemudian mematikan. Suhu di dalam ruangan dipengaruhi oleh kepadatan hunian, penyinaran matahari dan ventilasi rumah.

Kepadatan penghuni yang ditetapkan oleh Departemen Kesehatan RI, yaitu rasio luas lantai seluruh ruangan dibagi jumlah penghuni minimal $10 \mathrm{~m}^{2} /$ orang. Luas kamar tidur minimal $8 \mathrm{~m}^{2}$ dan tidak dianjurkan digunakan lebih 2 orang tidur dalam satu ruang tidur, kecuali anak dibawah umur 5 tahun. Kepadatan hunian dapat juga ditentukan dengan jumlah kamar tidur dibagi dengan jumlah penghuni (sleeping density), dinyatakan dengan nilai: baik, bila kepadatan lebih atau sama dengan 0,7 cukup, bila kepadatan antara 0,5 - 0,7 dan kurang bila kepadatan kurang dari 0,5 .

Daerah perkotaan (urban) yang lebih padat penduduknya dibandingkan di pedesaan (rural), peluang terjadinya kontak dengan penderita Tb paru lebih besar. Sebaliknya di daerah rural akan lebih kecil kemungkinannya. Dapat disimpulkan bahwa orang yang rentan (susceptible) akan terpapar dengan penderita $\mathrm{Tb}$ paru menular lebih tinggi pada wilayah yang padat penduduknya walaupun insiden sama antara yang penduduk padat dan penduduk tidak padat (Karyadi et al, 2006 dalam Martini 2007).

Kepadatan hunian akan memudahkan terjadinya penularan penyakit $\mathrm{Tb}$ paru di dalam rumah tangga. Bila dalam satu rumah tangga terdapat satu orang penderita $\mathrm{Tb}$ paru aktif dan tidak diobati secara benar maka akan menginfeksi anggota keluarga terutama kelompok yang rentan seperti bayi dan balita, semakin padat hunian suatu rumah tangga maka semakin besar risiko penularan (Karyadi et al, 2006 dalam Martini, 2007).

Faktor yang selanjutnya adalah kondisi ventilasi suatu rumah. Kondisi ventilasi berhubungan dengan minimal luas jendela/ventilasi yang harus ada dalam suatu rumah. Ventilasi yang baik harus meliputi $15 \%$ dari luas lantai. Ventilasi mempunyai fungsi sebagai berikut: (1) Menjaga agar aliran udara di dalam rumah tetap segar, sehingga keseimbangan $\mathrm{O}_{2}$ yang diperlukan oleh penghuni rumah tetap terjaga. Kurangnya ventilasi akan menyebabkan 
kurangnya $\mathrm{O}_{2}$ di dalam rumah yang berarti kadar $\mathrm{CO}_{2}$ yang bersifat racun bagi penghuninya menjadi meningkat, (2) Menjaga agar udara di ruangan rumah selalu tetap dalam kelembaban (humidity) yang optimum. Kelembaban yang optimal (sehat) yaitu sekitar $40-70 \%$ kelembaban yang lebih dari $70 \%$ akan berpengaruh terhadap kesehatan penghuni rumah. Kelembaban udara di dalam ruangan naik karena terjadinya proses penguapan cairan dari kulit dan penyerapan. Kelembaban ini akan merupakan media yang baik untuk bakteri bakteri patogen (penyebab penyakit), dan (3) Membebaskan udara ruangan dari bakteribakteri, terutama bakteri patogen, karena disitu selalu terjadi aliran udara yang terus menerus. Bakteri yang terbawa oleh udara akan selalu mengalir.

Lingkungan perokok dapat menyebabkan udara mengandung nitrogen oksida sehingga menurunkan kekebalan pada tubuh terutama pada saluran napas karena berkembang menjadi makrofag yang dapat menyebab infeksi. Selain itu ventilasi memiliki berbagai fungsi seperti membebaskan ruangan rumah dari bakteri pathogen terutama kuman tuberculosis. Kuman TB yang ditularkan melalui droplet nuclei dapat melayang di udara karena memiliki ukuran yang sangat kecil (50 mikron). Ventilasi yang tidak baik karena dapat menghalangi sinar matahari masuk ke dalam ruangan, padahal kuman TB hanya dapat dibunuh dengan sinar matahari secara langsung.

Faktor yang ketiga yang berperan dalam penyebaran kuman TB dalah suhu udara. Suhu udara yang ideal dalam rumah antara $18-30^{\circ} \mathrm{C}$. Suhu optimal pertumbuhan bakteri sangat bervariasi. Mycobacterium tuberculosis tumbuh optimal pada suhu $37^{\circ} \mathrm{C}$. Paparan sinar matahari selama 5 menit dapat membunuh $M$. tuberculosis dan tahan hidup pada tempat gelap, sehingga perkembangbiakan bakteri lebih banyak di rumah yang gelap. Bakteri $M$. tuberculosis merupakan bakteri mesofilik yang bisa hidup pada suhu udara $10-40^{\circ} \mathrm{C}$. Bakteri tahan hidup pada tempat gelap, sehingga perkembangbiakan bakteri lebih banyak di rumah yang gelap.

\section{Kesimpulan}

1. Pola persebaran kejadian penyakit Tb paru di Kota Malang membentuk pola kluster dengan ditunjukkan oleh nilai Zscore sebesar -17.16. Hal ini mengindikasikan bahwa perbedaan antara jarak tetangga terdekat (Nearest Neighbor) dari nilai hitung dan nilai yang diobservasi adalah signifikan meskipun mempunayi nilai yang lebih kecil dari yang diharapkan.

2. Berdasarkan hasil survei lapangan diketahui bahwa pengaruh lingkungan merupakan faktor yang menentukan besarnya jumlah penyakit TB Paru di Kota Malang. Diantaranya adalah tidak ada atau kurangnya ventilasi udara, tingkat kepadatan hunian dalam satu rumah, lantai tanah, kurangnya cahaya matahari yang masuk rumah, dan kondisi suhu udara.

3. Tingkat kerawanan penyakit TB Paru termasuk dalam tingkat sedang, hal ini karena pola spasial distribusinya termasuk pola spasial dengan kategori kluster. Dengan pola spasial yang mengkluster masih dapat segera dicegah dan dilakukan intervensi supaya tidak menyebar luas ke wilayah lain.

\section{Ucapan Terimakasih}

Terimakasih kepada Kemenristek Dikti yang telah memberikan dukungan material sehingga penelitian pada skema Hibah Dosen Pemula Tahun 2013 ini dapat terlaksana dengan baik. 


\section{Daftar Rujukan}

2011. Kota Malang Dalam Angka. Malang: Badan Pusat Statistik Kota Malang http://www.chronicdiseaseimpact.com/ebcd.taf?cat=index. (Akses 25 Desember 2012)

Bian. 2013. Spatial Approaches to Modelling Dispersion Communicable Diases-A Review, Departemen of Geography of Buffalo University, Jurnal Transactions in GIS 17(1): $1-17$

Chan, Wen, Wang, Fang. 2012. Spatial Dependency of Tuberculosis Incidence in Taiwan. PLoS ONE 7(11): e50740. doi:10.1371/journal.pone.0050740

Christine, Batista, Albuquerque, Pereira, Barbosa. 2012. Schistosomiasis transmission and environmental change: a spatio-temporal analysis in Porto de Galinhas, Pernambuco - Brazil. International Journal of Health Geographics (2012), 11:51 http://www.ij-healthgeographics.com/content/11/1/51

Cristiana J. Silva. 2013. Optimal control for a tuberculosis model with reinfection and postexposure interventions. Jurnal: Mathematical Biosciences 244 (2013) 154-164, Elsevier Inc. All rights reserved.

Drobniewski. 2013. Rapid diagnostics of tuberculosis and drug resistance in the industrialized world: clinical and public health benefits and barriers to implementation. London : BioMed Central Medicine (2013) 11:190 (open access article),

Fortin, Dale. 2005. Spatial Analysis (A guide for Ecologists. New York: Campbridge University Press

Kammerer, Shang, Althomsons, Haddad, Grant, Navin. 2013. Using statistical methods and genotyping to detect tuberculosis outbreaks. International Journal of Health Geographics 2013, 12:15. http://www.ij-healthgeographics.com/content/12/1/15

Lee, Wong. 2001. Statistical Analysis With Arcview GIS, John Wiley \& Sons, Inc.

Lillesand, Kiefer. 2004. Remote Sensing and Image Interpretation. John Wiley \& Sons,Inc. All Right Reserved.

Maheswaran, Craglia. 2004. GIS in Public Health Practise. Florida: CRC Press. LLC

Martiani. 2007. Analisis Risiko Penularan Tuberculosis Paru Akibat Faktor Perilaku dan Faktor Lingkungan Pada Tenaga Kerja Di Industri. Berita Kedokteran Masyarakat Vol. 23, No. 1, Maret 2007

Melnick. 2002. Introduction to Geographic Information Systems In Public Health. Maryland: Aspen Publishers. Inc.

Ruswanto. 2010. Analisis Spasial Sebaran Kasus Tuberkulosis Paru Ditinjau Dari Faktor Lingkungan Dalam dan Luar Rumah Di kabupaten Pekalongan 
Silva. 2013. Optimal control for a tuberculosis model with reinfection and post-exposure interventions. Mathematical Biosciences 244 (2013) 154-164

Simoonga, Utzingerc, Brookerd, Vounatsouc, Appletonf, Stensgaardg, Olseng, Kristensen. 2009. Remote Sensing, Geographical Information System and Spatial Analysis For Schistosomiasis Epidemiology and Ecology in Africa. Parasitology (2009), 136, $1683-1693$.

Cambridge University Press 2009. doi:10.1017/S0031182009006222. Printed in the United Kingdom. http://journals.cambriedge.org

Suharyo. 2013. Determinasi Penyakit Tuberkulosis Di Daerah Pedesaan. Jurnal Kesehatan Masyarakat. Kemas $\quad 9 \quad$ (1) $\quad$ (2013) 85-91. Http://journal.unnes.ac.id/nju/index.php/kemas

Waako. 2013. Burden of tuberculosis disease among adolescents in a rural cohort in Eastern Uganda. Uganda : BMC Infectious Diseases 2013, 13:349 (open access article),

Wahyuni, Houwing-duistermaat, Syafruddin, Supali,Yazdanbakhsh, Sartono. 2003. Clustering of filarial infection in an age-graded study: genetic, household and environmental influences. Parasitology (2004), 128, 315-321. DOI: 10.1017/S0031182003004487 Cambridge University Press

WHO. 2013. WHO Report 2013-Global Tuberculosis Control. www.who.int/tb/data. (Diakses tanggal 3 Juli 2019) 